\title{
Viability of lactic acid bacteria in two functional foods formulated with whey and malanga
}

\author{
Viabilidad de bacterias ácido lácticas en dos productos funcionales \\ formulados con lactosuero y malanga
}

\begin{abstract}
Alondra Guadalupe Santos-Vázquez, Arturo Alberto Velázquez-López and Gilber Vela-Gutiérrez*
Laboratorio de Investigación y Desarrollo de Productos Funcionales (LIDPF), Facultad de Ciencias de la Nutrición y Alimentos. Universidad de Ciencias y Artes de Chiapas. Lib. Norte Poniente 1150. Ciudad Universitaria, Col. Lajas Maciel. Tuxtla Gutiérrez, Chiapas. México. CP. 29000, Tuxtla Gutiérrez, Chiapas, México.
\end{abstract}

\section{ABSTRACT}

Whey, a cheese-derived product, contains good quality carbohydrates and proteins, which makes it a suitable medium for the bacterial development. Lactic acid bacteria (LAB) are used in foods to provide a wide variety of characteristics; these bacteria have been used for the production of edible films and antibacterial compounds that extend products shelf life. Our objective was to evaluate the viability of $L A B$ in two products formulated with whey and flour of malanga corms. The products were physical, microbiological and sensorially evaluated. By mixing two edible gums and Lactobacillus culture, a film was developed and applied to the bread crust added with whey and malanga flour; for the ice cream, first a fermented beverage was elaborated (48 hours) with Lactobacillus, the flavor was added and then frozen. The viability of the LAB was evaluated every week for a month in both products. The results indicate that the foods maintained a high growth of lactic acid bacteria $\left(>10^{6} \mathrm{CFU} / \mathrm{mL}\right)$. The best gums in the preparation of the coating were xanthan and malanga.

Keywords: whey, cocoyam, functional food

\section{RESUMEN}

El suero, un producto derivado de la producción de queso, tiene carbohidratos y proteínas de buena calidad, lo que lo convierte en un medio adecuado para el desarrollo de bacterias. Las bacterias ácido lácticas (BAL) se utilizan en los alimentos para proporcionar una amplia variedad de características; estas bacterias se han utilizado en la producción de películas comestibles y compuestos antibacterianos que extienden la vida útil del producto. El objetivo fue evaluar la viabilidad del BAL en dos productos formulados con suero lácteo y harina de cormos de malanga. Los productos fueron evaluados fisicoquímica, microbiológica y sensorialmente. Mezclando dos gomas comestibles y cultivo de Lactobacillus se desarrolló la película, que se aplicó a la cubierta de un pan adicionado con suero de leche y harina de malanga; para el helado, primero se elaboró una bebida fermentada (48 horas) con Lactobacillus, luego se adicionó el sabor y se congeló. Se evaluó la viabilidad de las BAL todas las semanas durante un mes en ambos productos. Los resultados indican que los alimentos mantuvieron un alto crecimiento de bacterias ácido lácticas (> 10 $\mathrm{UFC} / \mathrm{mL}$ ). Las mejores gomas en la elaboración del recubrimiento fueron xantana y malanga.

Palabras claves: Suero, malanga, alimento funcional

\section{INTRODUCTION}

Lactic acid bacteria (LAB) have been present in human diet since ancient times. Nowadays they can be found in different dairy products such as drinks, yoghurt, fresh and ripened cheeses, different meats and their products, and in some vegetables. In addition, these bacteria have been used in the food industry as bio-preservers (Martin del Campo et al., 2008) since they play an important role in fermentation processes, not only due to their acidification ability, but also to their involvement in texture, taste, odor and flavor development of foods (Parra, 2010). In recent decades, their use in perishable foods preservation has been explored, due to the production of various metabolites such as lactic acid, hydrogen peroxide, diacetyl, carbon dioxide $\left(\mathrm{CO}_{2}\right)$ and bacteriocins, the latter having stimulated greater interest (Heredia et al., 2017).

The malanga (Xanthosoma saggitifolium), is a plant with fast vegetative development, easy propagation and acceptable nutritional value. Using simple technologies, it is possible to use this vegetable to obtain flour, which can be used as raw material for the elaboration of various food products (Torres et al., 2013). Dehydrated malanga corm contains $90 \%$ dry matter, $80 \%$ carbohydrates, $7 \%$ raw protein, $4 \%$ raw fiber and $3 \%$ fat, as well as low levels of saponins, phytates and tannins (Lopez et al., 2018). In addition to macronutrients, corms have an important content of minerals, especially magnesium, calcium, iron and zinc, which are required to be included in the diet in order to fulfil vital functions of the human organism (Puá et al., 2019; Fernández et al., 2015; De Ancos et al., 2015).

Due to the important sector occupied by functional foods, the current trend of consuming these products, and the profits they produce, there is interest in adding beneficial bacteria to foods includingice cream, cereals, chocolate, non-fermented milk drinks; among them, ice cream is widely accepted among children and adolescents (Barrionuevo et al., 2011). 
These lactic acid bacteria, generally with probiotic characteristics, provide physiological effects such as intestinal $\mathrm{pH}$ reduction, production of some digestive enzymes, vitamins and antibacterial substances, reconstruction and construction of intestinal microbiota, reduction of blood cholesterol, elimination of carcinogenesis (Parra, 2010). The effectiveness of these bacteria depends on their viability and ability to adhere to the small intestine mucosa (Velazquez and Guerrero, 2014), also, it is necessary for them to resist adverse environments during processing, shelf life of the product and consumption, in addition to its passage through the gastrointestinal tract. Therefore, it is important to consider a series of technological factors during the process (Ramos et al., 2013).

Of the total milk produced in the state of Chiapas in México (423.6 million L), about $39 \%$ is used in the production of cheese (approximately 165.2 million L), discarding about 147.03 million $L$ of whey, with high nutritional value, to the rivers, causing serious environmental problems; considering that whey contains approximately $1 \%$ of protein, about 1.47 million $\mathrm{kg}$ of good quality protein are wasted annually in the state of Chiapas. The main component of whey is lactose, a sugar easily assimilated by LAB. Some of the nutritional advantages of the consumption of whey, is due to its high content of branched amino acids and immune system enhancers, which resist the digestion process, and therefore, are able to retain their specific values until they are absorbed through the long intestinal wall (Velazquez et al., 2018).

The objective of this research was to evaluate the viability of lactic acid bacteria (LAB), in two functional foods made from whey and malanga flour (Xanthosoma sagittifolium). The first is a low moisture product (bread), to which a coating (biofilm) was applied with $\angle A B$; and the second is a high moisture product (home ice cream) added with LAB.

\section{MATERIALS AND METHODS}

Whey was obtained at the Laboratory of Research and Development of Functional Products (LRDFP) of the University of Sciences and Arts of Chiapas (UNICACH), from the production of a fresh cheese; the whey had a slightly yellow color, a pleasant smell and a pH between 6 and 7. It was filtered to eliminate residues of the curd and impurities, pasteurized at temperature of $63 \pm 1^{\circ} \mathrm{C}$ for $30 \mathrm{~min}$, and stored in glass bottles previously sterilized until use.

\section{Product development Strain selection}

Prior to the production of the beverage, strains of Lactobacillus were inoculated into whey; the $\mathrm{pH}$ and $\%$ acidity of the whey at the beginning and during fermentation were monitored in order to obtain a beverage that would be used in the production of a probiotic film for bread and homemade ice cream. The bacteria used were isolated and characterized in our laboratory by Velazquez et al. (2018), from samples of fermented pozol (a typical zoque drink from the state of Chiapas, México). To make the beverage, 100 and $200 \mathrm{~mL}$ of sweet whey (previously pasteurized) were placed in flasks, each being inoculated with the strain at $10 \%$. After 48 hours, $\mathrm{pH}$ and \% of lactic acid ( $\left.{ }^{\circ} \mathrm{D}\right)$ were determined according to NOM-243- SSA1-2010, and CFU quantified in each beverage, using the dilution and plate casting technique (NOM- 092SSA 1-1994). Once the amount of LAB $\left(10^{6} \mathrm{CFU} / \mathrm{mL}\right)$ established by NOM-181- SCF1-2010 to be considered a probiotic beverage was reached, it was stored in refrigeration.

\section{Bread making}

The flour was prepared at the Laboratory of Research and Development of Functional Products (LRDFP), by dehydrating corm slices at a temperature of $60 \pm 1^{\circ} \mathrm{C}$ in a drying oven for 10 hours, grinding and sifting with a mesh or \#60 sieve to obtain the totally fine flour, packing in hermetically sealed bags and storing in a fresh and dry environment, until use. All dry ingredients (12\% whole meal flour, $19 \%$ wheat flour, $5 \%$ Malanga flour, $2 \%$ iodized salt, $55 \%$ brown sugar, $7 \%$ yeast) were placed in a stainless-steel container, slowly adding drinking water and whey, and mixed evenly until dough with the desired conditions was obtained. Olive oil was added to the dough obtained, to make "boleo" (rotary movements of the dough until the desired conditions were obtained). The whole dough was fermented for 30 minutes in a clean, disinfected container, covered with a completely clean cloth blanket. Subsequently, buns were formed and baked at $180^{\circ} \mathrm{C}$ for 20 minutes to make the bread.

\section{Coating production}

Under sterile conditions, the coating was made with the probiotic drink; two types of edible coating were made using different commercial gums (xanthan and carob). Two types of ice cream were also made with different concentrations of inoculum according to the experimental design shown in Table 1.

\section{Application of the covering}

Under sterile conditions, using a brush, the biofilm was applied to the crust of the bread, approximately 1-2 millimeters thick. The biofilm was allowed to dry, the product was placed in hermetically sealed bags and kept in refrigeration $\left(5^{\circ} \mathrm{C}\right)$; subsequently, the viability of the $L A B$ was evaluated weekly for four weeks.

\section{Homemade ice cream production}

The ice cream was made from a fermented whey beverage. The amount of BAL present in the drink must be greater than $10^{6} \mathrm{CFU} / \mathrm{mL}$. Coconut cream and natural fruit (pineapple) were added to the beverage; it was then frozen for 24 hours at $4^{\circ} \mathrm{C}$; the viability of the $L A B$ was evaluated, using the amount of CFU/mL of $L A B$ in the freshly produced products and during refrigerated storage for 4 weeks. The plate dilution and pouring method (NOM-092- SSA1-1994) was used, using MRS agar for lactobacillus (Difco ${ }^{\oplus}$ ). 
Table 1. Experimental design for coating and ice cream production. Tabla 1. Diseño experimental para el recubrimiento y helado casero.

\begin{tabular}{|c|c|c|c|}
\hline \multicolumn{4}{|c|}{ Coating } \\
\hline Treatment & BF: LAB (mL) & Xanthan gum & Carob gum \\
\hline BP1 & $20: 10$ & $0.8 \mathrm{~g}$ & --- \\
\hline BP2 & $20: 10$ & --- & $0.8 \mathrm{~g}$ \\
\hline \multicolumn{4}{|c|}{ Ice cream } \\
\hline Treatment & BF: LAB (mL) & \multicolumn{2}{|c|}{ Fruit and/or taste } \\
\hline $\begin{array}{l}\mathrm{H} 1 \\
\mathrm{H} 2\end{array}$ & $100: 10$ & Lemon & onut \\
\hline $\begin{array}{l}\mathrm{H} 3 \\
\mathrm{H} 4\end{array}$ & $200: 10$ & \multicolumn{2}{|c|}{ pineapple - coconut } \\
\hline
\end{tabular}

BF: Fermented beverage; BP: Coating; $\mathrm{H}$ : Ice cream

\section{Physicochemical analysis}

The nutritional composition of homemade bread and ice cream was determined by proximal chemical analysis: moisture content (AOAC 2015, 934.01), ash (AOAC 2015, 942.05), protein (AOAC 2015, 2001.11), ethereal extract (AOAC 1990, 920.39) and crude fiber (AOAC 2015, 962.09).

\section{Sensory evaluation}

For the sensory evaluation, we used a group of untrained judges made up of 20 students between 19 and 23 years of age from the University of Science and Arts of Chiapas, the sample was selected through a non-probabilistic sampling at convenience. The test performed was for acceptability using a structured survey. The attribute profile was determined using a verbal hedonic scale, in which the acceptability of the biofilm in probiotic bread and homemade ice cream was analyzed.

\section{Statistical analysis}

The results of the sensory evaluation were analyzed using binominal statistics $(p<0.005)$ and chi-square $(p<0.005)$, using the Minitab ${ }^{\oplus}$ Statistical Package, version 14.0 for Windows.

\section{RESULTS AND DISCUSSIONS}

Generally, coatings are formulated as liquid solutions that are applied on the surface of fruits or vegetables, to regulate the humidity and gaseous exchange with the atmosphere (Ncama et al., 2018; Thakur et al., 2018).

Before developing the biofilm, the strains were reactivated in the whey, with an initial pH of $6.8 \pm 0.4$ and an acidity of $14 \pm 0.31^{\circ} \mathrm{D}$; after 16 hours (exponential phase), $\mathrm{pH}$ and acidity of fermented whey were measured, resulting in $4.4 \pm$ 0.9 and $19 \pm 0.28$, respectively. Similar data were shown by Montesdeoca et al. (2017), who obtained a fermented whey beverage with a final pH of $4.5 \pm 0.035$; Alava et al. (2014) characterized a sweet whey obtaining a pH of $6.5 \pm 0.21$. Lactobacillus produces organic acids, mainly lactic acid, that modify the $\mathrm{pH}$ of foods, which in addition to possess antibacterial activity, it allows a greater release of calcium in the food, also, when consumed, allows a greater absorption of the same (Rojas et al., 2015).

Under sterile conditions, the bread was made with malanga and wheat flour. After baking the breads (Figure 1a) the probiotic biofilm was applied with commercial gums (xanthan and carob) (Figure 1c) and whey. The ingredients of the edible coatings can vary among gums, to replace materials and reduce typical polymer coatings. Currently, there are coatings based on protein, which makes them more attractive since, in addition to the various effects, they allow a nutritional increase of the product (Feng et al., 2018).

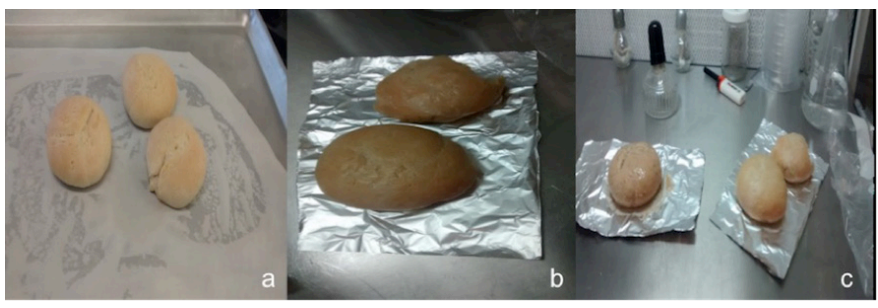

Figure 1. Breads with edible biofilms: a) Baking, b) Sterilization, and c) Inoculation.

Figura 1. Panes con biopelículas comestibles; a) Horneado, b) Esterilización c) Inoculación.

$L A B$ viability tests were performed on breads made with probiotic biofilms. They were evaluated once a week for four weeks, through the technique of dilution and emptying into plates. Depending on each dilution, Lactobacillus growth can be observed. Results obtained from the quantification of the viability of bread with xanthan gum biofilm are shown.

During bread storage, the results show a considerable growth reduction of $L A B$ after the second week $\left(10^{-2}\right.$ and $10^{-3}$ dilution), however, at the end of the four weeks of storage, the amount of $\mathrm{CFU} / \mathrm{mL}$ was greater than $1 \times 10^{6} \mathrm{CFU} / \mathrm{g}$ at the $10^{-1}$ dilution. It should be mentioned that this type of product remains on the shelf for about two weeks or less. The decrease in the bread CFU of LAB after the second week, is probably due to a decrease in the humidity of the product. It is necessary to emphasize that the biofilm allows the adequate development of $L A B$ so that the coating can be considered a functional product. Lactic acid bacteria have important roles in food production, showing the ability to inhibit growth and development of a wide variety of undesirable microorganisms in food. Some metabolites have a preservative effect by limiting the growth of pathogens, called bacteriocins (bioactive peptides), some have an effect on food quality by producing flavor enhancing components (diacetyl and acetaldehydes) (Agurto and Ramos, 2008; Heredia et al., 2017).

The biofilm with the carob bean gum allowed a greater growth of $L A B$, in the first week the amount of CFU/ $\mathrm{mL}$ was greater than $1 \times 10^{6} \mathrm{CFU} / \mathrm{g}$ in all dilutions; in the case of the $10^{-1}$ dilution, no count was possible throughout the four weeks of storage, whereas the $10^{-2}$ dilution, this behavior was only present during the first two weeks; after that, a notorious reduction in the amount of CFU present in the coating was observed, in the same way it was observed for the $10^{-3}$ dilution, after the first week. An anoxic culture of $L A B$ was developed in the coating, verified by gram staining, 
and bacteria in the form of bacilli with a blue coloration was observed, indicating the presence of gram (+) lactic acid bacteria (Ramirez et al., 2011) (figure 2). In addition, this type of edible coating has been used to increase the shelf life of cheeses, increasing their organoleptic quality, due to the fact that the polysaccharides used decrease gas exchange; in addition, the production of bacteriocins from LAB (Costa et al., 2018; Arnon and Poverenov, 2018).

A homemade probiotic ice cream was made, using different concentrations of the fermented beverage with Lactobacillus; this bacteria has a greater tolerance to acidity, to the presence of oxygen and to high concentrations of sugars (Ramos et al., 2012). Four formulations were made (table 1), varying the inoculum concentration (100 and 200 $\mathrm{mL}$ ) and the taste. The flavors used were pineapple-coconut and lemon. The desired characteristics, such as consistency, appearance, flavor, color, and creamy texture, were achieved (Figure 3). After preparing the ice cream mixes (Figure 3a), they were inoculated under sterile conditions (Figure 3b), air was added to obtain the desired mix (Figure 3c), resulting in the ice cream shown in Figure $3 \mathrm{~d}$ and $\mathrm{e}$.

The viability of $L A B$ in ice cream $(\mathrm{H} 1, \mathrm{H} 2, \mathrm{H} 3$ and $\mathrm{H} 4)$ was evaluated weekly for four weeks using the plate casting technique, with MRS agar. Table 4 shows that the ice creams contain high viability of LAB between the first and third week of storage; however, after the fourth week a decrease is observed. Due to the use of an anoxic culture and the concentration of Lactobacillus, this product is considered a simple probiotic ice cream (Ramos et al., 2012). Similar results were reported by Moussa et al. (2005) who developed a probiotic ice cream and analyzed viability of $L A B$ along 4 weeks of storage, finding a decrease from 0.8 to 0.7 log.

Pineapple, coconut and lemon fruit extracts were used for flavoring, since they are harvested in any season, and are readily available in the local market, as well as being a perfect medium for the survival and growth of lactic acid bacteria.

Breads with edible coating were counted for fungi and yeasts according to the NOM-247-SSA1-2008 method, which indicates a maximum limit of $300 \mathrm{CFU} / \mathrm{g}$. The presence of Salmonella and Shigella, aerobic mesophilic, total coliforms, Staphylococcus aureus and Vibrio cholerae was evaluated according to the NOM-243- SSA1-2010, as safety parameters.
Table 2. Microbiological evaluation results of homemade ice cream. Tabla 2. Resultados de la evaluación microbiológica del helado casero.

\begin{tabular}{|c|c|c|c|c|c|}
\hline \multicolumn{6}{|c|}{$\mathrm{H} 1$} \\
\hline \multirow{2}{*}{ Dilution } & \multicolumn{5}{|c|}{$\mathrm{CFU} / \mathrm{g}$} \\
\hline & Week 0 & Week 1 & Week 2 & Week 3 & Week 4 \\
\hline $10^{-1}$ & $>1 \times 10^{6}$ & $>1 \times 10^{6}$ & $>1 \times 10^{6}$ & $>1 \times 10^{6}$ & $>1 \times 10^{6}$ \\
\hline $10^{-2}$ & $>1 \times 10^{6}$ & $>1 \times 10^{6}$ & $>1 \times 10^{6}$ & $>1 \times 10^{6}$ & $>1 \times 10^{6}$ \\
\hline $10^{-3}$ & $>1 \times 10^{6}$ & $>1 \times 10^{6}$ & $>1 \times 10^{6}$ & $\begin{array}{c}131000 \\
\pm 9.89\end{array}$ & $\begin{array}{c}112500 \\
\pm 3.53\end{array}$ \\
\hline \multicolumn{6}{|c|}{$\mathrm{H} 2$} \\
\hline \multirow{2}{*}{ Dilution } & \multicolumn{5}{|c|}{$\mathrm{CFU} / \mathrm{g}$} \\
\hline & Week 0 & Week 1 & Week 2 & Week 3 & Week 4 \\
\hline $10^{-1}$ & $>1 \times 10^{6}$ & $>1 \times 10^{6}$ & $>1 \times 10^{6}$ & $>1 \times 10^{6}$ & $>1 \times 10^{6}$ \\
\hline $10^{-2}$ & $>1 \times 10^{6}$ & $>1 \times 10^{6}$ & $>1 \times 10^{6}$ & $>1 \times 10^{6}$ & $>1 \times 10^{6}$ \\
\hline $10^{-3}$ & $>1 \times 10^{6}$ & $>1 \times 10^{6}$ & $>1 \times 10^{6}$ & $>1 \times 10^{6}$ & $\begin{array}{r}121000 \\
\pm 12.72 \\
\end{array}$ \\
\hline \multicolumn{6}{|c|}{$\mathrm{H} 3$} \\
\hline \multirow{2}{*}{ Dilution } & \multicolumn{5}{|c|}{$\mathrm{CFU} / \mathrm{g}$} \\
\hline & Week 0 & Week 1 & Week 2 & Week 3 & Week 4 \\
\hline $10^{-1}$ & $>1 \times 10^{6}$ & $>1 \times 10^{6}$ & $>1 \times 10^{6}$ & $>1 \times 10^{6}$ & $>1 \times 10^{6}$ \\
\hline $10^{-2}$ & $>1 \times 10^{6}$ & $>1 \times 10^{6}$ & $>1 \times 10^{6}$ & $>1 \times 10^{6}$ & $>1 \times 10^{6}$ \\
\hline $10^{-3}$ & $>1 \times 10^{6}$ & $>1 \times 10^{6}$ & $>1 \times 10^{6}$ & $>1 \times 10^{6}$ & $>1 \times 10^{6}$ \\
\hline \multicolumn{6}{|c|}{$\mathrm{H} 4$} \\
\hline \multirow{2}{*}{ Dilution } & \multicolumn{5}{|c|}{$\mathrm{CFU} / \mathrm{g}$} \\
\hline & Week 0 & Week 1 & Week 2 & Week 3 & Week 4 \\
\hline $10^{-1}$ & $>1 \times 10^{6}$ & $>1 \times 10^{6}$ & $>1 \times 10^{6}$ & $>1 \times 10^{6}$ & $>1 \times 10^{6}$ \\
\hline $10^{-2}$ & $>1 \times 10^{6}$ & $>1 \times 10^{6}$ & $>1 \times 10^{6}$ & $>1 \times 10^{6}$ & $\begin{array}{l}13600 \\
\pm 5.65\end{array}$ \\
\hline $10^{-3}$ & $>1 \times 10^{6}$ & $>1 \times 10^{6}$ & $\begin{array}{c}44000 \pm \\
15.55\end{array}$ & $\begin{array}{c}19000 \pm \\
4.24\end{array}$ & $\begin{array}{c}8000 \\
\pm 4.24\end{array}$ \\
\hline
\end{tabular}

The fungi and yeasts count showed a growth of less than $10 \mathrm{CFU} / \mathrm{g}$, well within the specifications indicated by the NOM-181-SCF1-2010. Lactic acid bacteria have been used as food biopreservatives, due to the production of secondary metabolites named bacteriocins, which inhibit the growth of pathogenic or alter microorganisms present in the raw

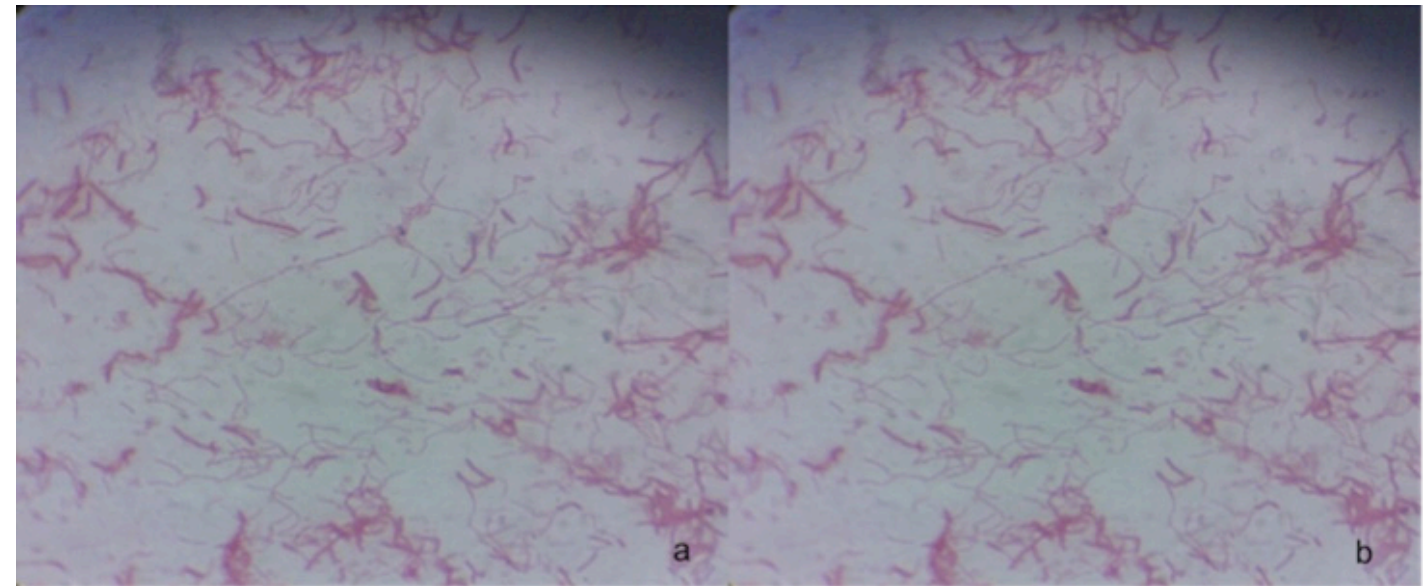

Figure 2. BAL strains observed $(100 \mathrm{X})$ under the optical microscope (gram stain).

Figura 2. Cepas de BAL observadas (100 X) al microscopio óptico. 


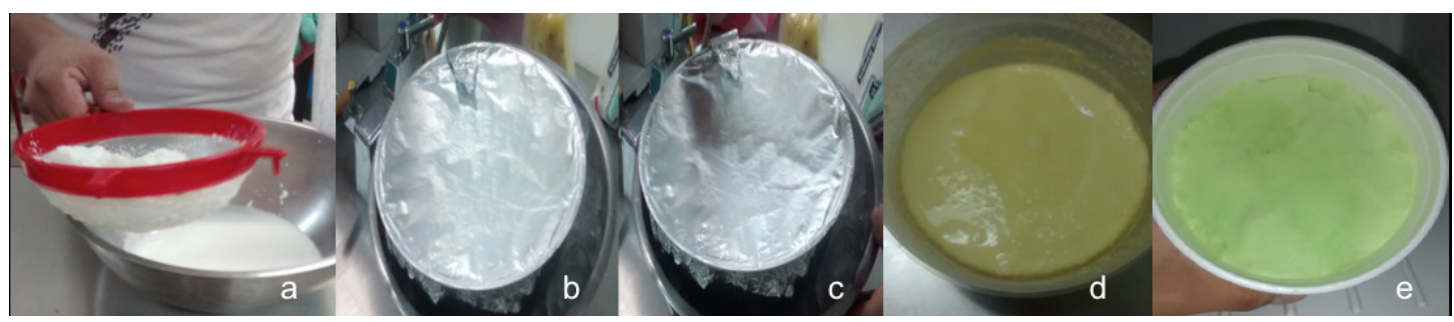

Figure 3. Homemade probiotic ice cream process: a) preparation, b) inoculation, c) air incorporation, d) and e) final ice cream. Figura 3. Proceso de elaboración de helados caseros probióticos: a) preparación, b) Inoculación, c) incorporación de aire, d) y e) helados finales.

Table 3. Microbiological analysis results of bread coated with probiotic biofilms.

Tabla 3. Resultados del análisis microbiológico del pan con recubrimiento probiótico.

\begin{tabular}{lll}
\hline Parameter & Result (CFU/g) & Limit $^{\mathrm{A}}$ (CFU/g) \\
\hline Mold and yeasts & $<10$ & 300 \\
\hline Aerobic mesophiles & 10,000 & 200,000 \\
\hline Total Coliforms & Absent & 100 \\
Mold and yeasts & 10 & 50 \\
Staphylococcus aureus & Absent & $<100$ \\
Salmonella & Absent & Absent in 25 g \\
\hline
\end{tabular}

A NOM-247-SSA1-2008; NOM-036-SSA1-1993.

Table 4. Proximal chemical analysis of bread with probiotic coating: Xanthan gum (bread A) and carob gum (sample).

Tabla 4. Análisis químico proximal del pan con recubrimiento probiótico: Goma Xantana (Pan A) y goma Algarrobo (Pan B).

\begin{tabular}{lcc}
\hline Parameter & Bread A & Bread B \\
\hline Moisture & $30.41 \pm 2.30$ & $37.34 \pm 3.99$ \\
Ash & $1.56 \pm 0.18$ & $1.14 \pm 0.05$ \\
Fat & $0.69 \pm 0.13$ & $0.85 \pm 0.30$ \\
Protein & $1.64 \pm 0.75$ & $2.45 \pm 0.72$ \\
Fiber & $6.75 \pm 0.03$ & $6.75 \pm 0.03$ \\
\hline Carbohydrates & $60.32 \pm 3.03$ & $54.29 \pm 4.06$ \\
\hline
\end{tabular}

material. The optimal development of LAB contributes to the preservation of food, reducing the use of chemical preservatives, without altering the quality and safety of the product made (Agudelo et al., 2015). Lactic acid bacteria provide many beneficial effects related to their consumption, among which are the modulation of the intestinal microbiota activity, reduction of lactose intolerance symptoms, improvement of mucosal immunity and intestinal transit, and prevention of the incidence of Helicobacter pylori (Vinderola, 2014).

All the results shown in table 5, are lower than the maximum limits established by the Mexican official standard, to be considered fit for consumption, which guarantees the consumer health. Table 6 presents the results of the proximal chemical analysis of breads made with the different biofilms (with xanthan gum, bread A; and with carob gum, bread B). The results of the ice cream proximal chemical analysis are shown in Table 7. Due to the fact that the bread pieces were made with whey and the application of coating, the humidity
Table 5. Proximal chemical analysis results of pineapple-coconut ice cream added with $100 \mathrm{~mL}$ of whey (Ice cream A) and lemon ice cream added with $200 \mathrm{~mL}$ of whey (Ice cream B).

Tabla 5. Resultados del análisis químico proximal del helado de piña -coco con $100 \mathrm{~mL}$ de lactosuero (Helado A) y el helado de limón con $200 \mathrm{~mL}$ de lactosuero (Helado B).

\begin{tabular}{lcc}
\hline Parameter & Ice cream A & Ice cream B \\
\hline Moisture & $70.61 \pm 0.24$ & $73.06 \pm 0.15$ \\
Ash & $0.34 \pm 0.03$ & $0.27 \pm 0.01$ \\
Fat & $0.67 \pm 0.30$ & $0.16 \pm 0.09$ \\
Protein & $0.46 \pm 0.0$ & $0.64 \pm 0.26$ \\
Fiber & $1.74 \pm 0.26$ & $1.79 \pm 1.26$ \\
\hline Carbohydrates & $26.18 \pm 0.77$ & $24.08 \pm 0.93$ \\
\hline
\end{tabular}

Table 6. Degree of acceptability by untrained judges according to bread attribute profile.

Tabla 6. Grado de aceptabilidad de jueces no entrenados de acuerdo al perfil de atributos del pan.

\begin{tabular}{lcccccccc}
\hline $\begin{array}{l}\text { Level of } \\
\text { satisfaction }\end{array}$ & \multicolumn{2}{c}{ Color } & \multicolumn{2}{c}{ Smell } & \multicolumn{2}{c}{ Taste } & \multicolumn{2}{c}{ Appearance } \\
\cline { 2 - 9 } & M451 & M581 & M451 & M581 & M451 & M581 & M451 & M581 \\
\hline Like & $21^{\mathrm{aA}}$ & $11^{\mathrm{ab}}$ & $19^{\mathrm{aA}}$ & $13^{\mathrm{aB}}$ & $19^{\mathrm{aA}}$ & $13^{\mathrm{aB}}$ & $16^{\mathrm{aA}}$ & $23^{\mathrm{aA}}$ \\
Neutral & $1^{\mathrm{bA}}$ & $4^{\mathrm{bA}}$ & $2^{\mathrm{bA}}$ & $5^{\mathrm{bA}}$ & $3^{\mathrm{bA}}$ & $8^{\mathrm{bB}}$ & $4^{\mathrm{bB}}$ & $0^{\mathrm{bB}}$ \\
Unlike & $1^{\mathrm{bA}}$ & $8^{\mathrm{aB}}$ & $2^{\mathrm{bA}}$ & $5^{\mathrm{bA}}$ & $1^{\mathrm{bA}}$ & $2^{\mathrm{CA}}$ & $3^{\mathrm{bA}}$ & $0^{\mathrm{bA}}$ \\
\hline
\end{tabular}

*Different letters in the same column per sample indicate significant statistical differences ( $p<0.05$, chi-square).

*Different letters in the same row per attribute indicate significant statistical differences $(p<0.05$, chi-square).

obtained was high compared to other types of bread (Mohammad et al., 2003; Ishida and Steel, 2014), as well as the rest of the parameters determined. One of the options for fortifying bakery products is the use of alternative flours as an ingredient in their preparation. Each flour has unique nutritional characteristics, for example, oats and barley increase the content of $\beta$-glucans (fibre) (Pourafshar et al., 2014), as does malanga flour, which also has exceptional nutritional and functional properties. In the baking industry, several additives are used to improve dough properties, increase quality and tolerance to food processes, and generally used to optimize products shelf life. However, currently there are alternatives to avoid the use of harmful additives, of which the use of edible coatings stands out, which can increase positive health effects (Andressa et al., 2017).

The mineral content (ash) of bread $A$ and $B$ is similar to that of whey (Hernández and Vélez, 2014), both are low in fat 
Table 7. Degree of acceptability by untrained judges according to homemade ice cream attribute profiles.\}

Tabla 7. Grado de aceptabilidad de jueces no entrenados de acuerdo al perfil de atributos de helado casero.

\begin{tabular}{|c|c|c|c|c|c|c|c|c|c|c|c|c|c|c|c|c|}
\hline \multirow{2}{*}{$\begin{array}{l}\text { Level of } \\
\text { satisfaction }\end{array}$} & \multicolumn{4}{|c|}{ Color } & \multicolumn{4}{|c|}{ Smell } & \multicolumn{4}{|c|}{ Taste } & \multicolumn{4}{|c|}{ Appearance } \\
\hline & M273 & M324 & M451 & M355 & M273 & M324 & M451 & M355 & M273 & M324 & M451 & M355 & M273 & M324 & M451 & M355 \\
\hline Like & $15^{\mathrm{aA}}$ & $8^{\mathrm{aB}}$ & $12^{\mathrm{aA}}$ & $11^{\mathrm{aA}}$ & $17^{\mathrm{aA}}$ & $10^{\mathrm{aB}}$ & $9^{a \mathrm{~B}}$ & $6^{\mathrm{ac}}$ & $19^{\mathrm{aA}}$ & $9^{a B}$ & $1^{\mathrm{ac}}$ & $16^{\mathrm{aA}}$ & $12^{\mathrm{aA}}$ & $13^{\mathrm{aA}}$ & $10^{\mathrm{aA}}$ & $9^{\mathrm{aA}}$ \\
\hline Un like & $3^{\mathrm{bA}}$ & $7^{\mathrm{aB}}$ & $8^{\mathrm{aB}}$ & $9^{a \mathrm{~B}}$ & $3^{\mathrm{bA}}$ & $3^{\mathrm{bA}}$ & $4^{\mathrm{bA}}$ & $5^{\mathrm{aA}}$ & $2^{\mathrm{bA}}$ & $5^{\mathrm{bA}}$ & $19^{\mathrm{bB}}$ & $3^{\mathrm{bA}}$ & $3^{\mathrm{bA}}$ & $7^{\mathrm{aB}}$ & $8^{\mathrm{bB}}$ & $7^{\mathrm{aB}}$ \\
\hline
\end{tabular}

*Different letters in the same column per sample indicate significant statistical differences ( $p<0.05$, chi-square).

*Different letters in the same row per attribute indicate significant statistical differences ( $p<0.05$, chi-square).

and fiber since they are made from whole wheat and white wheat flour, and malanga flour. Fiber has different effects on the quality of the products, it can influence volume, increase firmness, and promote color changes (Pourafshar et al., 2014). According to Andressa et al. (2017), edible coatings in bakery products, allow an increase of their quality, considering coatings which are based on proteins, gums, with functional compounds, among others, increasing the nutritional value.

The ice cream ash, fiber, moisture and protein content is similar in both; they have low fat content, however the pineapple-coconut ice cream presented higher fat content, compared to the lemon flavor $(p<0.05)$. It should be mentioned that this difference is due to the presence of coconut in ice cream A. Within its composition, we can highlight the presence of polyunsaturated fatty acids (PUFA), vitamins and minerals, which due to its composition, we can attribute some benefits, such as antioxidant properties, ability to regulate blood pressure, and decrease triglycerides. According to Januário et al. (2018), commercial products generally have basic ingredients (milk, milk powder, sugar, salt, sucralose, vegetable oil and fruit pulp) and many others, such as carboxymethylcellulose, guar gum, monoglycerides, monostearate, polysorbate 60 , modified starch, corn starch, fumaric acid, artificial flavor and color. The results found here are similar to those reported by Barrionuevo et al. (2011), where they made a prebiotic ice cream added with blueberry, which obtained a humidity of $60 \%$.

With respect to the evaluation of the profile of attributes (odor, flavor, color and appearance), figure 4 shows the number of people who liked the product per sample. It can be seen that 16 people ( $80 \%$ ) preferred sample 451 , elaborated with xanthan gum, while four people $(20 \%)$ liked sample 581 , elaborated with carob bean gum. The bread with the biofilm made with xanthan gum (sample 451), presented greater acceptability due to all the attributes that the gum provides to the product.

The level of enjoyment of four attributes (odour, flavour, colour and appearance/appearance) with untrained judges obtained for ice cream with different amounts of inoculum and different flavors (pineapple-coconut and lemon), is shown in table 9. It is clear that three samples (M273, M451 and M355) presented the highest level of enjoyment $(p<0.05)$; while M324, showed no statistical difference with respect to the three levels of enjoyment evaluated. Sample M273, is the one that showed the highest $(p<0.05)$ level of liking regar-

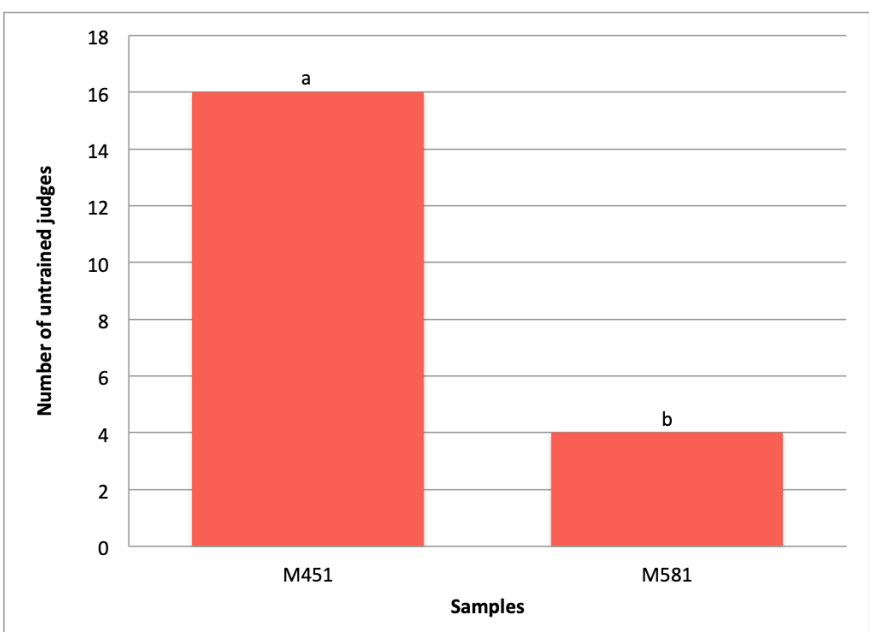

Figure 4. Number of untrained judges according to the degree of acceptability in breads with probiotic biofilms ( $p<0.05$, chi-square).

Figura 4. Número de jueces no entrenados de acuerdo al grado de aceptabilidad en panes con biopelículas probióticas ( $p<0.05$, chi-cuadrada).

ding the odor attribute, while the rest of the samples (M324, M451 and M355) did not show a high level of liking. Samples M273 and M355, showed statistically $(p<0.05)$ the highest level of palatability; however, samples M432 and M451 were not selected by the judges as the highest level of palatability with respect to the taste attribute. Regarding the appearance attribute, samples M324 and M451, showed the highest level of liking by the judges, while the other two samples showed a low level of liking, without statistical differences $(p<0.05)$. According to Pandiyan et al. (2012), and Markowiak and Slizewska (2017), symbiotic ice cream (probiotic and prebiotic), has little effect on the aromatic profile.

Figure 5, shows that samples 324 and 273 (pineapplecoconut flavor) have the highest level of preference, while samples 451 and 355 (lemon flavor) were the least preferred, probably due to the acidity. In the same figure, the level of enjoyment of each flavor of the homemade ice cream (pineapple-coconut and lemon) is shown. The test performed with the untrained judges, who were instructed to rate the pineapple-coconut ice cream samples, in each of the respective papers, at the end of the evaluation they were instructed to rate the lemon-flavored ice cream samples; the results indicate that the pineapple-coconut ice cream was the one with the highest acceptability by the judges (I like it very much, and I like it slightly); while the lemon-flavored ice cream, in the two inoculum concentrations presented a lower level of liking (I like it slightly, and I unlike it slightly). 


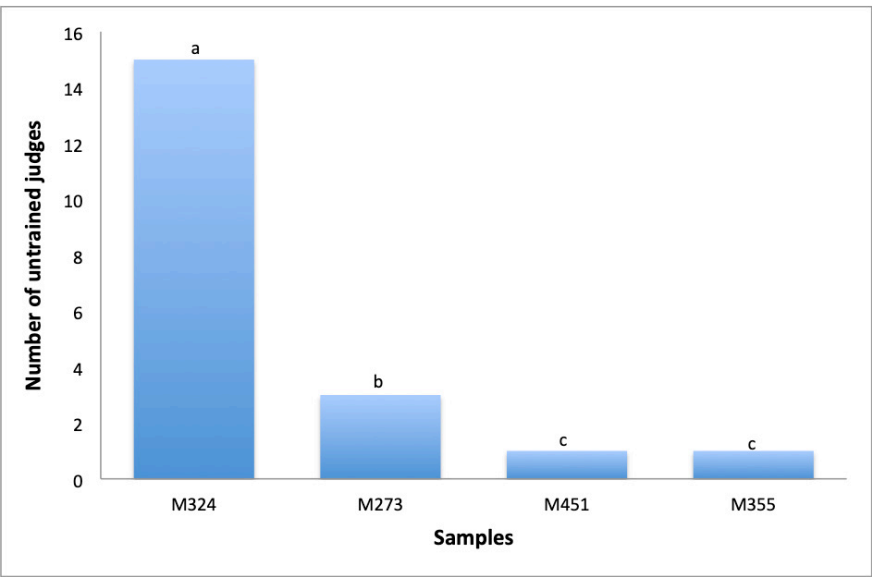

Figure 5. Number of untrained judges according to the degree of acceptability in samples of homemade ice cream ( $p<0.05$, chi-square).

Figura 5. Número de jueces no entrenados de acuerdo al grado de aceptabilidad en muestras de helado casero ( $p<0.05$, chi cuadrada).

\section{CONCLUSIONS}

The microbiological results indicate a high concentration of LAB in both products (bread and ice cream), above than established in the NOM-181-SCF1-2010, so they can be considered as probiotic foods. The presence of malanga flour in breads provides very important nutritional characteristics, plus it is necessary to improve the quality of the product, such is the case of fiber, proteins, minerals and vitamins. This opens an excellent opportunity to develop different bakery products, with a wide shelf life. The presence of whey in both products makes it possible to maintain the viability of $L A B$ in both products, due to the presence of sugars (lactose) that can be assimilated by the strains. The presence of $L A B$, as well as bioactive peptides from whey, in addition to some components such as fiber and antioxidants from malanga, allows both products to be classified as functional foods. The use of malanga and whey in a combined or separate way, opens a wide possibility for the generation of functional products that improve the health and nutritional conditions of people, as well as to generate innovative prototypes that impact positively on the reduction of environmental problems that are currently presented.

\section{ACKNOWLEDGMENTS}

The authors would like to thank the reviewers of the professional thesis of Alondra Guadalupe Santos Vázquez, as well as the academic technicians of the Faculty of Nutrition Sciences and Food of the University of Sciences and Arts of Chiapas, who contributed to the achievement of the degree in Science and Food Technology.

To the SADER - CONACYT Sectorial Fund for granting financial resources for the implementation of the project "Development of technologies for the use of malanga corms (Xanthosoma sagittifolium) from the state of Chiapas and Veracruz" with code 2016-01-277457.

\section{REFERENCES}

Agudelo, N., Torres, M., Alvarez, C., Vélez, L. 2015. Bacteriocinas producidas por bacterias acido lácticas y su aplicación en la industria de alimentos. Revista de la Asociación Colombiana de Ciencia y Tecnología de Alimentos. 23(36): 186-205.

Agurto, T., Ramos, J.C. 2008. Bacterias ácido lácticas: biopreservantes de los alimentos. Biotempo. 8: 54- 64.

Alava, C., Gómez, M., Maya, J. 2014. Caracterización fisicoquímica del suero de leche obtenido de la producción de queso casero en el municipio de Pasto. Revista Colombiana de Investigaciones Agroindustriales. 1:22-32.

Andressa, M., Zambeli, R., Araújo, A., Bastos, M. 2017. Edible coating on modified corn starch/tomato powder: Effect on the quality of dough bread. LWT-Food Science and Technology. 89: 518-524.

Armon, H y Poverenov, E. 2018. Improving food products' quality and storability by using Layer by Layer edible coating. Trends in Food Science and Technology. 75: 81-92.

Ayub, M., Wahab, S., Durrani, Y. 2014. Effect of water activity (Aw) Moisture Content and Total Microbial Count on the Overall Quality of Bread. International Journal of Agricultural Biology. 5(3): 274-278.

Barrionuevo M., Carrasco, J., Cravero, B., Ramón, A. 2011. Formulación de un helado dietéticos sabor arándano con características prebióticas. DIAETA. 29(134) 23-28.

Costa, M., Maciel, L., Teixeira, J., Vicente, A., Cerqueira, M. 2018. Use of edible films and coatings in cheese preservation: Opportunities and Challenges. Food Research International. 107: 84-92.

De Ancos, B., Gonzalez, D., Colina, C., Sánchez, C. 2015. Uso de películas/recubrimientos comestibles en los productos de IV y V gama. Revista Iberoamericana de Tecnología Poscosecha. 16(1): 8-17.

Feng, Z., Wu, G., Liu, C., Li, D., Jiang, D., Zhang, X. 2018. Edible coating based on whey protein isolate nanofibrils for antioxidant and inhibition of product browning. Food Hydrocolloids. 79:179-188.

Fernández, D., Bautista, S., Fernández, D., Ocampo, A., García, A., Falcón, A. 2015. Peliculas y recubrimientos comestibles: una alternativa favorable en la conservación poscosecha de frutas y hortalizas. Revista Ciencias Técnicas Agropecuarias. 24(3): 52-56.

Heredia, P., Hernandez, A., Cordova, A., Vallejo, B. 2017. Bacteriocinas de bacterias ácido lácticas: Mecanismo de acción y actividad antimicrobiana contra patógenos en quesos. Interciencia. 42(6): 340-346.

Hernández, M., Vélez, J. 2014. Suero de leche y su aplicación en la elaboración de alimentos funcionales. Temas selectos de Ingeniería de Alimentos. 8(2): 13-22.

Ishida, P., Steel, C. 2003. Physicochemical and sensory characteristics of pan bread samples available in the Brazilian market. Food Science and Technology. 34(4): 746-754.

Januário, H., Oliveira, A., Dias, S., Klososki, S., Pimentel, T. 2018. Kefir ice cream with fruits and sweetened with honey: physical and chemical characteristics and acceptance. International Food Research Journal. 25(1): 179-187.

López, B., Pinos, J., Devezé, P., Espin, T., Pérez, P. 2018. Efecto de la substitución de maíz por cormo de malanga (Colocasia esculenta) en la degradación in vitro de dietas y en el desarrollo de corderos pelibuey. Agrociencia. 52: 97-105. 
Markowiak, P., Slizewska, K. 2017. Effects of Probiotics, Prebiotics, and Synbiotic on Human Health. Nutrients. 9: 1-30.

Martin del Campo, M., Cástulo, I., Gómez, H., Héctor, E., Alaníz, O. 2008. Bacterias acidolacticas con capacidad antagónica y actividad bacteriocinogenica aisladas de quesos frescos. e-Genosis. 6(5): 1-17.

Montesdeoca, R., Benítez, I., Guevara, R., Guevara, G. 2017. Procedimiento para la producción de una bebida láctea fermentada utilizando lactosuero. Revista Chilena de Nutrición. 44(1): 39-44.

Moussa, S., Fatma, F., Awad, R. 2005. Production of probiotic ice cream. Polish Journal of food and nutrition science. 14 (3): 267-271.

Ncama, K., Samukelo, L., Mdtishwa, A., Zeray, S. 2018. Plantbased edible coating for managing postharvest quality of fresh horticultural produce: A review. Food Packaging and Shelf life. 16: 157-167.

Pandiyan, C., Annal, R., Kumaresan, G., Murugan, B., Gopalakrishnamurthy, T. AÑO. Development of symbiotic ice cream incorporating Lactobacillus acidophilus and Saccharomyces boulardii. International Food Research Journal. 19(3): 1233-1239.

Parra, R. A. 2010. Review. Bacterias ácido lácticas: Papel funcional en los alimentos. Facultad de Ciencias Agropecuarias. 8(1): 93-105.

Pourafshar, S., Rosentrater, K., Padmanaban, G. 2014. Using alternative flours as partial replacement of barbari bread formulation (traditional Iranian Bread). Journal Food Science and Technology. 52(9): 5691- 5699.

Puá, A., Barreto, G., Zuleta, J., Herrera, O. 2019. Análisis de nutrientes de la raíz de malanga (Colocasia esculenta Schott) en el trópico seco de Colombia. Información Tecnológica. 30(4): 69-76.
Ramírez, J.C., Ulloa, P, Velázquez, M.Y., Ulloa, J., Arce, F. 2011. Bacterias lácticas: Importancia en alimentos y sus efectos en la salud. Revista Fuente. 2(7): 1-16.

Ramos, G., Hernández, L. H., Fernández, S. G., Froto, M., Vázquez, L. 2013. Estrategias para mejorar la sobrevivencia de probióticos en helados. Biotecnia. 15(2): 31-38.

Rojas, A., Montaño, L., Bastidas, M. 2015. Producción de ácido láctico a partir del lactosuero utilizando Lactobacillus delbruekii subsp. Bulgaricus y Streptococcus thermophilus. Revista Colombiana de Química. 44(3): 5-10.

Thakur, R., Pristojono, P., Golding, J., Stathopoulos, C., Scarlett, C., Bowyer, M., Singh, S., Vuong, Q. 2019. Starch- based films: Major factors affecting their properties. International Journal of Biological Macromolecules. 132: 1079-1089.

Torres, A., Montero, P., Duran, M. 2013. Propiedades fisicoquímicas, morfológicas y funcionales del almidón demalanga (Colocasia esculenta). Revista Lasallista de Investigación. 10(2): 52-61.

Velázquez, A. y Guerrero, J. 2014. Algunas investigaciones recientes en recubrimientos comestibles aplicados en alimentos. Temas selectos de Ingeniería de Alimentos. 8(2): 5-12.

Velázquez, A., Covatzin, D., Dolores, M., Vela, G. 2018. Bebida fermentada elaborada con bacterias ácido-lácticas aisladas del pozol tradicional chiapaneco. Ciencia UAT. 13(1): 1-19.

Vinderola, G. 2014. Bacterias probióticas en productos lácteos fermentados. Anuales Academicos de Ciencias Exactas, Física y Naturales. 6:5-2 